\title{
Keynesian economics: can it return if it never died?
}

\author{
Barry Eichengreen \\ George C. Pardee and Helen N. Pardee Professor of Economics and Political Science, University of \\ California, Berkeley, CA, USA
}

\begin{abstract}
Appreciation of the Keynesian synthesis was enhanced by the events of the last decade. The global financial crisis highlighted the fragility of financial markets and the capriciousness of animal spirits. The depth of the downturn pointed to the value of not just automatic stabilizers but also discretionary fiscal policy as tools of macroeconomic management. Keynesian models and not their New Classical challengers provided the practical analytical framework for policy design. Models of the anti-Keynesian effects of fiscal consolidation received little support from actual consolidation experience. The secular-stagnation debate that followed the crisis lent legitimacy to the view that policy-makers with fiscal space were wise to use it.
\end{abstract}

Keywords: Keynesian economics, monetary policy, fiscal policy

JEL codes: $B 00, E 00$

\section{INTRODUCTION}

A symposium with the title 'Keynesian economics - back from the dead?' begs two questions. Does everyone mean the same thing when they say Keynesian economics? And who says it died in the first place?

My own interpretation of Keynesian economics derives from two sources. The first is James Tobin - appropriately for a symposium organized around the Godley-Tobin Lecture - from whom I took graduate macro- and monetary economics. Tobin's definition of Keynesian macroeconomics, as he taught it or at least as I learned it, was Hicks's IS-LM model augmented with a financial sector distinguishing assets with different durations and risk characteristics, where asset demands were specified consistently and subject to explicit stock-flow relationships and adding-up constraints (see Tobin 1969; Brainard and Tobin 1968).

The second source was discussions and debates with Alec Cairncross, with whom I collaborated in the 1980s. Alec and I had friendly disagreements about how to model monetary and fiscal policies in the three devaluations of sterling about which we were writing. ${ }^{1}$ Specifically we disagreed about whether monetary policy was still effective in an environment of low interest rates, or whether the economy was entirely dependent on fiscal policy for impetus under such circumstances. Having been one of the co-authors of the Radcliffe Report (Radcliffe Committee 1959), Alec doubted the

1. Britain devalued like clockwork, every 18 years, on each occasion around the time of a full moon. See Cairncross and Eichengreen (1983). 
existence of a stable link between monetary policy and economic activity in the presence of low interest rates, and for that matter in a variety of other circumstances. I explained what I had learned at the knee of Tobin: that monetary policy, by altering relative supplies of different financial assets, as in the case of Operation Twist, the Federal Reserve's early 1960s experiment, could still influence relative returns, portfolio allocations, and investment and other spending decisions. Alec looked at me and responded, 'Well, Keynes didn't see it that way when I was at Cambridge in the 1930s.' That put an end to the matter.

A cat can't change its stripes. I will therefore argue that Keynesian economics in the sense of IS-LM augmented by a fully specified financial sector never died, although it may have gone into hibernation. If anything, its influence, intellectually and over policy, increased as a result of the global financial crisis. In contrast, the Keynesian argument that monetary policy has no impact on economic activity, in general and specifically at the zero lower bound, suffered a mortal blow as a result of this recent history. This particular aspect of Keynesian economics is not back from the dead. The 2008-2009 financial crisis and the policy response were just the last nails in its coffin.

\section{FROM THE RADCLIFFE REPORT TO THE GREAT INFLATION}

Keynes himself acknowledged an important role for monetary policy in regulating the economy. This was evident in the Tract (1923), in The Economic Consequences of Mr. Churchill (1925), and in Keynes's interrogation of Montagu Norman in the context of his private evidence to the Macmillan Committee (Keynes 1981). ${ }^{2}$ Keynes of The General Theory (1936) is known better for observing that there are special circumstances in which conventional monetary-policy tools may be ineffective. As he put it in the relevant passage,

there is the possibility ... that, after the rate of interest has fallen to a certain level, liquiditypreference may become virtually absolute in the sense that almost everyone prefers cash to holding a debt which yields so low a rate of interest. In this event the monetary authority would have lost effective control over the rate of interest. (Ibid., p. 207)

The familiar implication is that there is an argument under such circumstances for the active use of fiscal policy. Less well remembered, however, is the sentence immediately following the two quoted above: 'But whilst this limiting case might become practically important in the future, I know of no example of it hitherto' (ibid.). Thus, even the Keynes of The General Theory argued that there was a role for both monetary and fiscal policies in economic stabilization under virtually all circumstances. The General Theory was not just about employment but also about interest and money. Nonetheless, there was a tendency on the part of authors writing in the Keynesian tradition to focus on the special case of the liquidity trap that was one of the new departures of The General Theory. Thus, Hicks (1937, p. 158), in his formulation of the IS-LM model, depicted an LM curve that was very elastic at low interest rates and emphasized that 'an imperfectly elastic monetary system - a rising [LM] curve' - was needed to prevent monetary policy from being rendered impotent and avoid having the economy sink into an unstable equilibrium.

Post-World War II experience reinforced this skepticism about the utility of monetary policy for stabilization purposes. The United Kingdom emerged from the war with

2. A comparison of the proceedings and reports of the Macmillan and Radcliffe Committees is Gordon (1972). 
a heavy public debt and a newly nationalized central bank. Interest rates were immobilized by the need to limit debt service, much as was the case in the United States prior to the Treasury-Fed Accord of March 1951. Monetary policy as an instrument of economic management was then reactivated in 1951, owing to the advent of a Conservative government. This was part of a bargain in which the new government largely eliminated rationing and cut taxes on purchases of consumer durables, measures whose impact on aggregate demand could be offset by higher interest rates if need be.

In 1955, when inflationary pressures intensified and the balance of payments weakened, monetary policy was tightened, in the first real test of the new instrument. The bank rate was raised from 3 percent to $3 \frac{1}{2} 2$ percent in late January, and to $4 \frac{1}{2}$ percent in late February. To policy-makers' surprise, bank borrowing continued to rise, and there was little abatement of inflationary and balance-of-payments pressures. The result disillusioned those who had assumed a stable relationship between interest rates on the one hand and credit conditions and spending on the other. Thus chastened, the authorities resorted to directly restricting the extension of credit to rein in demand. This unhappy experience with conventional monetary policy prompted the appointment of the Radcliffe Committee and informed its report, in turn shaping Keynesian views of the ineffectiveness of monetary policy for the better part of two decades.

The portions of the Radcliffe Report that were most easily remembered and that most powerfully shaped policy focused on the instability of the link between monetary aggregates and economic activity. The Radcliffe Committee rejected the existence of a stable link between the quantity of money and aggregate demand, owing to the instability of the velocity of circulation (Radcliffe Committee, pp. 388-389). Members were skeptical of the existence of stable and predictable effects of changes in the level of interest rates on saving, inventory investment, and even fixed investment (ibid., pp. 450 and 460). These observations suggested that reliance for macroeconomic stabilization should be placed on fiscal policy and credit controls. It was these measures and not conventional monetary policy on which the British authorities consequently focused when attempting to regulate demand, inflation, and the balance of payments. ${ }^{3}$

A more careful reading of the Radcliffe Report would have led to a more nuanced view. The committee's explanation for the absence of a stable relationship between short-term interest rates and spending decisions was that spending was influenced by the entire term structure of interest rates (Radcliffe Committee, p. 395). Its explanation for the absence of a stable relationship between the money stock and aggregate demand lay in the impact on spending of the entire range of 'easily realizable [liquid] financial assets' (ibid., p. 389). To a student of Tobin, this sounds like the Keynesian synthesis of IS-LM with a disaggregated financial sector, where the demand for financial assets with different durations and risk characteristics depends on the entire vector of expected returns on that range of assets, and in which the elements of that vector collectively influence spending decisions. This alternative interpretation of the Keynesian synthesis, more prevalent perhaps in the US than the UK, was conducive to the more active use of monetary policy, in the 1950s as an instrument limiting inflation and in the 1960s as a device for moving up and down what was thought to be a stable Phillips curve (Romer and Romer 2002). As a consequence, Keynesian economics came to mean something different on the two sides of the Atlantic. ${ }^{4}$

3. See Cairncross (1996, pp. 243-261). A recent assessment is Aikman et al. (2019).

4. I would argue that this transatlantic divide over monetary policy was much more consequential than the Cambridge-Cambridge capital-theory controversy that played out in parallel. 
This consensus, or more precisely lack of consensus, was shattered by the Monetarist counter-revolution and the acceleration of inflation, two not unrelated developments. Milton Friedman's intellectual influence derived from a powerful interpretation of the role of monetary factors in the Great Depression, and from a theory of the expectationsaugmented Phillips curve that provided an explanation for the observed instability of the relationship between monetary policy and unemployment. ${ }^{5}$ These ideas were then incorporated into the Keynesian synthesis in response to the acceleration of inflation, in the US and UK and more broadly, in the late 1960s and 1970s. Monetary policy, this experience made clear, had a significant if not always perfectly predictable impact on inflation. Whether it could also be used to manage unemployment - whether it could be used to exploit the Phillips curve - was now understood to depend on how it affected expectations.

Unfortunately, adaptive expectations, the assumption of convenience employed by Keynesian economists and others, was unsatisfactory analytically and empirically. Investigators did not yet understand the importance of the broader monetary policy strategy - what modern analysts call the 'regime' - and of central-bank communication in conveying that strategy. This in turn opened the door to another assumption of convenience, namely rational expectations. The idea that policy could be accurately forecast by rational agents meant that, at the limit, systematic monetary policy could have no real effects. The irony, then, was that the 'rational expectations revolution' provided intellectual justification for the views of the authors of the Radcliffe Report concerning the lack of utility of monetary policy.

\section{FROM RICARDIAN EQUIVALENCE TO THE CREDIT CHANNEL}

There remained the Keynesian argument for the active use of fiscal policy. This too was challenged by the rational expectations revolution and by the rediscovery of Ricardian equivalence. ${ }^{6}$ Ricardian equivalence is the idea that an increase in the budget deficit bequeaths a debt that has to be serviced with higher taxes in the future. Under restrictive conditions, the present value of the additional taxes will exactly equal the present value of the additional government spending. Rational forward-looking consumers anticipate those taxes. Since they reduce consumption to offset their higher tax burden, there will be no change in aggregate demand and no real effects of fiscal policy. Thus, Ricardian equivalence was invoked to challenge the Keynesian presumption favoring fiscal policy for stabilization purposes. ${ }^{7}$

Did Ricardian equivalence in fact drive a stake through the heart of Keynesian economics? There are at least two reasons to reject this conclusion. First, Ricardian equivalence, even on its own terms, does not eliminate the effectiveness of temporary fiscal stimulus. Temporary deficit spending today still implies higher taxes, but those higher taxes are spread over time, assuming the existence of long-term debt. In this case the reduction in household consumption commensurate with those higher taxes offsets only a portion of the additional public spending. And the Keynesian argument for deficit spending in a downturn is an argument for temporary deficit spending. ${ }^{8}$

5. See Friedman and Schwartz (1963) and Friedman (1968) respectively.

6. See Barro (1974; 1979).

7. This was an argument that again reared its head in the 2008-2009 financial crisis.

8. Adherents of 'Modern Monetary Theory' (discussed below) have been known to argue for a permanent increase in deficit spending. But these arguments differ from those of the Keynesian synthesis supposedly challenged by Ricardian equivalence. 
Second, Ricardian neutrality assumes the existence of frictionless capital markets. But if households are credit-constrained - if they are unable to borrow when their incomes evaporate in a slump - then even a permanent increase in deficit spending will not induce a further reduction in private spending. This point may have been highlighted insufficiently by Keynes's disciples, since Keynes himself did not draw a strong distinction between money and credit or formally analyse credit markets (Bertocco 2005). Hicks's IS-LM model distinguished only an explicit demand for money and an implicit demand for bonds, therefore lacking full-fledged credit markets. Even Brainard and Tobin followed Keynes in treating financial assets as essentially stores of wealth rather than sources of credit. Some, like Minsky, never lost sight of the distinction, but only in the 1980s, motivated by the challenge from the proponents of Ricardian equivalence, did authors working in the Keynesian tradition add credit markets and liquidity constraints to the canonical model. ${ }^{9}$

Not incidentally, this focus on the credit channel also helped to rehabilitate the argument for the effectiveness of monetary policy under normal conditions. If asymmetric information creates moral hazard and adverse selection, then bank loans will be rationed, preventing households from smoothing their consumption and firms from investing. Monetary policy will then affect lending, borrowing, and spending by increasing bank reserves, reducing the cost of bank lending, and relaxing credit constraints. Conversely, increases in interest rates in response to a monetary contraction will reduce the present value of collateralizable net worth against which banks are prepared to lend, increasing the cost of external finance. This last channel operates even if open-market operations or a change in interest rates have no direct quantity effect on the ability and willingness of banks to lend - à la the UK in 1955.

Thus, both monetary and fiscal policies can be seen as effective stabilization tools even in the presence of rational, optimizing agents and forward-looking behavior, assuming only imperfections in the information environment. This was the mainstream view prior to the global financial crisis, as represented by discussions and scholarship at, inter alia, the NBER Summer Institute, the Brookings Panel on Economic Activity, and the Kansas City Fed's Jackson Hole Symposium.

\section{FROM THE GLOBAL FINANCIAL CRISIS TO THE ZERO LOWER BOUND}

Different implications might follow, however, if the economy was at the zero lower bound. Recall that Keynes, while pointing to this case as a theoretical curiosum, could not recollect an instance of it. ${ }^{10}$ The early 1930 s came closest, but even that precedent was imperfect.

Thus, there was little empirical basis for verifying the Keynesian proposition of the ineffectiveness of monetary policy at the zero lower bound. Fortunately for empirical economists, if not also for the residents of the countries concerned, this constraint was relaxed by Japan in the 1990s and then by the US and Europe starting in 2008.

The evidence, as I read it, is inconsistent with the textbook Keynesian proposition that monetary policy is ineffective when interest rates approach zero so that 'liquiditypreference may become virtually absolute.' For one thing, we learned that zero is not

9. See Bernanke (1983) and Bernanke and Gertler (1995) for example.

10. While Keynes was presumably focusing on the immediately preceding decades, recent research by Schmelzing (2019) going much further back in time suggests that the probability of hitting the zero lower bound becomes even more remote the further back one goes. 
the lower bound; central banks can push rates down further. They can charge negative rates on deposits with the central bank, providing a pecuniary incentive for banks to limit their excess reserves and engage in additional lending. Evidence from Europe suggests that banks subject to this policy increased their investments in sovereign bonds, including foreign bonds, while also raising their lending (Demiralp et al. 2016).

Concern is voiced that negative rates make banking riskier by compressing margins between lending rates and the still positive rates paid to depositors. This concern is misplaced insofar as the goal of policy in depressed economic conditions is precisely to encourage banks to take on additional risk. That said, there may be reason to worry if that additional risk is concentrated in a small handful of banks - those relying most heavily on retail funding - and if regulation is not adjusted accordingly (see Nucera et al. 2017).

Similarly, recent evidence suggests that central-bank balance-sheet policies, or quantitative easing (QE), can be effective even at the zero lower bound. This would not have surprised early-1960s fans of Operation Twist. If QE appeared to give only a limited boost to the economy, this was not because it was ineffective but because it was implemented tentatively in the aftermath of the global financial crisis, owing to resistance from critics who opposed it on political or economic grounds.

Empirical studies identify two channels through which central-bank asset purchases influenced economic activity. First, through the operation of the portfolio-balance channel, central-bank purchases of treasury and mortgage-backed securities led investors to replace them with long-term corporate bonds, driving down corporate spreads (even AAA corporate borrowing rates remaining well above the zero lower bound) and encouraging investment (Gagnon et al. 2011). This mechanism rests on the imperfect substitutability of different financial assets that is a staple of Keynesian portfolio theory (Bernanke 2010).

Second, the central bank can use asset purchases to signal market participants of its intentions (Krishnamurthy and Vissing-Jorgensen 2011; Christensen and Rudebusch 2012). ${ }^{11}$ If it can signal that short-term interest rates will remain lower in the future, it will place downward pressure on long-term interest rates today, following standard term-structure arbitrage logic. ${ }^{12}$ The central bank's concern with its own balance sheet that it will take capital losses on its investments if interest rates rise - may make this signal credible. Central banks' purchases of long-term government bonds that shorten the term structure of government debt held by the public may similarly deter the central bank from raising short-term rates. This may send a credible signal if the central bank is concerned with not just its own balance sheet but that of the consolidated public sector (Bhattarai et al. 2015).

\section{FISCAL POLICY AND THE CRISIS}

Nothing trained more attention on Keynesian arguments than the use of fiscal policy in the global financial crisis. In the United States, fiscal stimulus was opposed by entities such as the Committee for a Responsible Federal Budget that perceived a bias toward excessive deficit spending. It was opposed by Republicans in the Congress, who saw it

11. Explicit forward guidance, which was sometimes used in conjunction with balance-sheet policies, works in the same direction.

12. The logic is that long-term rates should equal the average of current and expected future short-term rates over the relevant horizon, since investors should be indifferent between rolling over a short-term loan and committing to a long-term loan. 
as government expansion by stealth. It was criticized by economists who misinvoked Ricardian equivalence. It was dismissed by critics who observed that recovery was U-rather than V-shaped and that unemployment remained elevated for an extended period.

Subsequent research concluded that the slow pace of recovery was a result of the limited magnitude, not the limited effectiveness, of fiscal stimulus, reflecting political resistance to more forceful action. Nakamur and Steinsson (2014) analysed the macroeconomic effects of changes in military procurement at the state level, arguing that these were unlikely to be contaminated by simultaneity bias. Chodorow-Reich et al. (2012) considered the employment effects of Medicaid transfer to states, focusing on the component that was unrelated to changes in the state's economic circumstances. Chodorow-Reich (2019) mapped these cross-sectional multipliers into the national, no-monetary-policy-response multiplier, obtaining values as high as 2 . Auerbach and Gorodnichenko (2012) showed that multipliers were larger in recessions than expansions, consistent with Keynesian intuition.

The controversy also led investigators to revisit the evidence on fiscal policy in the 1930s, the low-interest-rate environment that most closely resembled the aftermath of the global financial crisis. Almuna et al. (2010) exploited the fact that there was variation across countries in defense spending. Hausman (2016) took advantage of the fact that there was a largely exogenous increase in US government outlays in 1936 owing to pay-out of the Veterans' Bonus and that the presence of World War I veterans varied significantly across states. These studies found spending multipliers in the range of 1.5 to 2 .

Finally, there was evidence from the winding down of the Obama Stimulus starting in 2010 and the shift to austerity in Europe. It was claimed previously (Alesina et al. 1998), again at the time (Alesina and Ardagna 2010), and subsequently (Alesina et al. 2019) that fiscal policy could have anti-Keynesian effects - that consolidation could be expansionary. This anti-Keynesian result was likely to obtain, the argument ran, when debt burdens were high and there were grounds for doubting debt sustainability. In these circumstances, fiscal consolidation's positive impact on sustainability and confidence might outweigh its direct negative effect on aggregate demand.

This argument hinged on the credibility of the claim that debts were unsustainable. ${ }^{13}$ It turned on the assumption than enhanced confidence would have a positive impact on private spending sufficient to offset the direct negative impact on aggregate demand. My reading of the evidence (in Eichengreen 1998 and subsequently) is that the only cases where contractionary fiscal policy was neutral or positive in its effect were when monetary policy was loosened, the exchange rate depreciated significantly, and external (export) demand was available to replace the domestic demand that was lost.

These were not the conditions prevailing in 2010. Euro area countries lacked a national exchange rate to depreciate and a national monetary policy to adjust. The dollar was elevated by safe-haven flows and by the efforts of emerging markets, complaining of 'currency wars,' to limit the appreciation of their own currencies. China may have been lapping up raw materials and energy, but the global environment for merchandise exports was weak. The last word on fiscal policy in this period was Blanchard and Leigh (2013), who found that planned fiscal consolidation was associated with lower-than-forecast growth, as if fiscal multipliers were not just positive but even larger than previously assumed.

13. An issue to which I return below. 


\section{FROM THE ZERO LOWER BOUND TO SECULAR STAGNATION}

No sooner did the advanced economies show signs of recovering from the global financial crisis than the focus shifted to secular stagnation. Although the immediate impetus was the slow pace of recovery, attention quickly shifted to broader and more long-lived issues. The advanced countries displayed not just slow rates of GDP and productivity growth (Fernald et al. 2017) but also an unusually low natural rate of interest (Laubach and Williams 2003). These post-crisis conditions were in fact continuations of ongoing trends: the decline in rates of output and productivity growth and in the natural rate of interest had been under way for years, even decades, before 2008-2009.

Secular stagnation is a classic Keynesian trope. In 'Economic possibilities for our grandchildren' (1931), Keynes raised the question of whether consumption would keep pace with productivity. In the 1939 American Economic Association presidential address in which he coined the term, Alvin Hansen suggested that declining population growth might mean slower spending growth. That Hansen subsequently became a leading exponent of Keynesian economics was not unrelated to his worries about chronically deficient demand. In a series of speeches and presentations, Lawrence Summers (2014) then drew parallels between Hansen's arguments on the one hand and the current condition of slow growth and low interest rates on the other.

Explanations for the declining natural rate of interest do not stop with demography. ${ }^{14}$ Summers's preferred addition was the rising importance of intangible capital relative to tangible capital in a high-tech twenty-first-century world, which means less spending on physical capital and lower interest rates. Mine is the falling relative price of capital equipment, which reduces investment-spending requirements, assuming an elasticity of substitution between capital and labor of less than unity, consistent with the majority of empirical studies (Eichengreen 2015).

These different interpretations have a common implication. That investment is equated with saving at historically low interest rates suggests that it may be possible to increase deficit spending without crowding out significant amounts of investment and pushing rates up to uncomfortable heights. ${ }^{15}$ Rachel and Summers (2019) suggest that, absent the budget deficits of advanced-country governments in recent decades, neutral real interest rates would have declined significantly more than actually observed and that risk-free rates in all likelihood would be significantly negative. In turn this raises the specter of an underemployment equilibrium, of the sort of which Keynes warned, if nominal interest rates cannot decline much below zero, governments are not prepared to run deficits, and central banks are unable or unwilling to raise inflation significantly above prevailing low levels. ${ }^{16}$

14. Indeed some recent work (Borio et al. 2017) questions the generality of the link between demographics and real interest rates.

15. Specifically, there may be more scope than otherwise for public spending on infrastructure, education, and basic research.

16. At the same time, the prevailing low level of interest rates means that there will be relatively little room for monetary stimulus of the conventional variety in future downturns. Thus, the rediscovery of secular stagnation reinforces the Keynesian presumption of the need to supplement monetary policy with fiscal policy and if anything to prioritize the latter. 


\section{KEYNESIAN ECONOMICS AND $r-g$}

The explanation for rising wealth inequality in Piketty (2014) is that the real interest rate $(r)$ is greater than the real growth rate $(g)$, so that income from capital, which depends on $r$, grows faster than the income of workers, which depends on $g$. In this setting, the wealth distribution becomes more unequal, an implication for which there is support in recent experience. At the same time, growth does not falter, since relatively high returns indicate that the capital stock has not been pushed beyond the Golden Rule (Phelps 1961).

How are these observations reconciled with the secular-stagnation literature suggesting that real interest rates have been trending downward to the point where, absent policy support, they may now be negative? How are they reconciled with the evidence in Blanchard (2019) that $r<g$, and not the opposite, has been the normal condition in a wide range of advanced countries?

The answer to both questions is that the rate of return on risky private capital is higher than the rate of return on safe government debt. There's no reason why the rate of interest paid on public debt can't be below the growth rate, while the return on capital is simultaneously above it, if there exists a sufficiently large risk premium. Assuming an equity premium of 5 percent, the historical norm, this reconciliation is entirely plausible. ${ }^{17}$

But if the required return on government debt is below the growth rate of the economy, there may be more scope for running deficits and accumulating debt. If $r<g$ in the absence of additional deficits, then the numerator of the debt-to-GDP ratio will be growing more slowly than its denominator, causing the debt burden to fall, whatever its initial value. It is then not the case that the advanced countries are about to tumble over a fiscal cliff. Auerbach and Gorodnichenko (2017) provide empirical validation for these ideas, showing that government-spending shocks do not lead to persistent increases in debt-to-GDP ratios in periods of economic weakness.

Whether the additional deficits made possible by this fiscal space are welfareimproving depends on the model. In Blanchard's model of $r<g$ and full employment equilibrium, a government can use deficits to source and provide residents with additional goods and services only at some cost in terms of crowding out investment in private capital. ${ }^{18}$ In Summers's model of $r<0$ and an underemployment equilibrium, there may be no such trade-off; larger deficits are unambiguously welfare-improving. The caveat is that real interest rates may rise if, for whatever reason, risk-free government debt is re-rated as risky. In this case, the sustainable becomes unsustainable. ${ }^{19}$

This last observation points to a key difference between secular stagnation (the idea that the real natural rate is uncomfortably low or even negative) and Monetary Monetary Theory (MMT, as in Mitchell et al. 2019). MMT, as I read it (different

17. A separate issue is that an equity premium of this magnitude is difficult to derive assuming standard microfounded investment behavior, in which asset demands depend on the covariance of returns with consumption growth. In particular, Mehra and Prescott (1985) showed that observed covariances can generate an equity premium of this order of magnitude only if one makes implausible assumptions about the degree of risk aversion of investors.

18. That cost depends on the marginal product of capital and on whether high observed returns reflect mainly the productivity of investment or rents due to imperfect competition.

19. 'For whatever reason' alludes to the fact that the required return can rise for either justified or unjustified reasons, but in either case with the same implications for sustainability. 
people read it differently), denies the possibility that government debt can be re-rated as risky. Governments have a debt purchaser of last resort in the central bank. If a country has its own currency, that central bank can always print money sufficient to absorb the government debt that private investors fail to buy. Default is therefore not a risk.

While it is correct that a government which issues debt in its own currency and possesses an obedient central bank has the technical means to avoid default, it is not clear that it also possesses the political means. At some point, monetary injections lead to inflation; if private investors, seeing the central bank engaging in inflationary finance, grow more reluctant to buy and hold government bonds, then the central bank will have to engage in still more inflationary finance. Those incurring the costs of inflation are not the same as those incurring the costs of debt default. In practice, government bonds are held by foreign as well as domestic investors, while the nation's money is used predominantly at home. ${ }^{20}$ It is conceivable, at some point, that a government favoring its citizens will chose default over inflation.

MMT has the merit of viewing the balance sheets of the central government and central bank in a consolidated way. Its strength is that it analyses government debt and surpluses in conjunction with private debt and surpluses. It emphasizes that government deficits which boost output and employment may raise private savings, as in Godley's sectoral-balances framework (note again the name of the lecture motivating this symposium). Conversely, it suggests that additional private savings, if they exceed investment at positive real interest rates, may depress tax revenues, lower public saving, and require fiscal deficits in order to be offset (as in the secular-stagnation literature). It insists that monetary and fiscal policies are most effective when used in tandem.

No one questions these points. What can be questioned is that the US and other advanced countries will remain, inevitably and indefinitely, in a situation where the rate of interest on government debt is less than the rate of economic growth.

\section{CONCLUSION}

The Keynesian synthesis is alive and well, but it is back from the dead only if you think it died in the first place. Whatever you think about this last point, appreciation of that synthesis was enhanced by the events of the last decade. The global financial crisis highlighted the fragility of financial markets and the capriciousness of animal spirits. The depth of the downturn pointed to the value of not just automatic stabilizers but also discretionary fiscal policy as tools of macroeconomic management. Keynesian models and not their New Classical challengers provided the practical analytical framework for policy design. Models of the anti-Keynesian effects of fiscal consolidation received little support from actual consolidation experience. The secular-stagnation debate that followed the crisis lent legitimacy to the view that policy-makers with fiscal space were wise to use it.

One proposition overturned by recent experience was that monetary policy is impotent when interest rates approach zero. Experiments with unconventional monetary

20. Proponents of MMT make this point when they emphasize the United States' 'exorbitant privilege' - that the country is currently able to borrow abroad by issuing dollar-denominated debt instruments that are willingly held as international reserves - until which point, it is tempting to add, they are no longer willingly held. 
policies showed that asset purchases and forward guidance can still have real effects in an environment of zero or negative nominal rates. This finding would have surprised the members of the Radcliffe Committee. But it would not have surprised scholars who appended an explicit, disaggregated financial sector to the Keynesian model. It would not have surprised Keynes himself.

\section{REFERENCES}

Aikman, David, Oliver Bush, and Alan Taylor (2019), 'Monetary versus macroprudential policy: causal impacts of interest rates and credit controls in the era of the UK Radcliffe Report,' Unpublished Manuscript, Bank of England and UC Davis.

Alesina, Alberto and Silvia Ardagna (2010), 'Large changes in fiscal policy: taxes versus spending,' Tax Policy and the Economy, 24, 35-68.

Alesina, Alberto, Roberto Perotti, and Jose Tavares (1998), 'The political economy of fiscal adjustments,' Brookings Papers on Economic Activity, 29, 197-266.

Alesina, Alberto, Carlo Favero, and Francesco Giavazzi (2019), Austerity: When It Works and When It Doesn't, Princeton, NJ: Princeton University Press.

Almuna, Miguel, Agustin Benetrix, Barry Eichengreen, Kevin O'Rourke, and Gisela Rua (2010), 'From Great Depression to Great Credit Crisis: similarities, differences and lessons,' Economic Policy, 25, 219-265.

Auerbach, Alan and Yuriy Gorodnichenko (2012), 'Measuring the output responses to fiscal policy,' American Economic Journal: Economic Policy, 4, 1-27.

Auerbach, Alan and Yuriy Gorodnichenko (2017), 'Fiscal stimulus and fiscal sustainability,' NBER Working Paper No 23789, September.

Barro, Robert (1974), ‘Are government bonds net wealth?' Journal of Political Economy, 82, 1095-1117.

Barro, Robert (1979), 'On the determination of the public debt,' Journal of Political Economy, 87, 940-971.

Bernanke, Ben (1983), 'Nonmonetary effects of the financial crisis in the propagation of the Great Depression,' American Economic Review, 73, 257-276.

Bernanke, Ben (2010), 'The economic outlook and monetary policy,' Speech at the Federal Reserve Bank of Kansas City's Jackson Hole Symposium, August.

Bernanke, Ben and Mark Gertler (1995), 'Inside the black box: the credit channel of monetary policy transmission,' Journal of Economic Perspectives, 9, 27-48.

Bertocco, Giancarlo (2005), 'The role of credit in a Keynesian monetary economy,' Review of Political Economy, 17, 489-511.

Bhattarai, Saroj, Gauti Eggertsson, and Bulat Gafarov (2015), 'Time consistency and the duration of government debt: a signaling theory of quantitative easing,' NBER Working Paper No 21336.

Blanchard, Olivier (2019), 'Public debt and low interest rate,' Presidential Address at the American Economic Association meetings, 4 January.

Blanchard, Olivier and Daniel Leigh (2013), 'Growth forecast errors and fiscal multipliers,' American Economic Review Papers and Proceedings, 103, 117-120.

Borio, Claudio, Piti Disyatat, Mikael Juselius, and Phurichai Rangcharoenkitkul (2017), 'Why so low for so long? A long-term view of real interest rates,' Unpublished Manuscript, Bank for International Settlements, December.

Brainard, William and James Tobin (1968), 'Pitfalls in financial model building,' American Economic Review, 58, 99-122.

Cairncross, Alec (1996), Managing the British Economy in the 1960s: A Treasury Perspective, London: Palgrave Macmillan.

Cairncross, Alec and Barry Eichengreen (1983), Sterling in Decline: The Devaluations of 1931, 1949 and 1967, Oxford: Blackwell.

Chodorow-Reich, Gabriel (2019), 'Geographical cross-sectional fiscal spending multipliers: what have we learned?' American Economic Journal: Economic Policy, 11, 1-34. 
Chodorow-Reich, Gabriel, Laura Feiveson, Zachary Liscow, and William Woolston (2012), 'Does state fiscal relief during recessions increase employment? Evidence from the American Recovery and Reinvestment Act,' American Economic Journal: Economic Policy, 4, 118-145.

Christensen, Jens and Glenn Rudebusch (2012), 'The response of interest rates to U.S. and U.K. quantitative easing,' Economic Journal, 122, F385-F414.

Demiralp, Selva, Jens Eisenschmidt, and Thomas Vlassopoulos (2016), 'The impact of negative interest rates on bank balance sheets: evidence from the euro area,' Unpublished Manuscript, Koc University and European Central Bank, April.

Eichengreen, Barry (1998), 'Comment,' Brookings Papers on Economic Activity, 29, 255-260.

Eichengreen, Barry (2015), 'Secular stagnation: the long view,' American Economic Association Papers and Proceedings, 105, 66-70.

Fernald, John, Robert Hall, James Stock, and Mark Watson (2017), 'The disappointing recovery of output after 2009,' Brookings Papers on Economic Activity, Spring, 1-58.

Friedman, Milton (1968), 'The role of monetary policy,' American Economic Review, 58, 1-15.

Friedman, Milton and Anna Schwartz (1963), A Monetary History of the United States, 18671960, Princeton, NJ: Princeton University Press.

Gagnon, Joseph, Matthew Raskin, Julie Remache, and Brian Sack (2011), 'Large-scale asset purchases by the Federal Reserve: did they work?' International Journal of Central Banking, 7, 3-43.

Gordon, Scott (1972), 'Two monetary inquiries in Great Britain: the Macmillan Committee of 1931 and the Radcliffe Committee of 1959,' Journal of Money, Credit and Banking, 4, 957-977.

Hansen, Alvin (1939), 'Economic progress and declining productivity growth,' American Economic Review, 29, 1-15.

Hausman, Joshua (2016), 'Fiscal policy and economic recovery: the case of the 1936 veterans' bonus,' American Economic Review, 106, 1100-1143.

Hicks, John (1937), 'Mr. Keynes and the “Classics”: a suggested interpretation,' Econometrica, $5,147-159$.

Keynes, John Maynard (1923), A Tract on Monetary Reform, London: Macmillan.

Keynes, John Maynard (1925), The Economic Consequences of Mr. Churchill, London: Macmillan.

Keynes, John Maynard (1931), 'Economic possibilities for our grandchildren,' in John Maynard Keynes, Essays in Persuasion, London: Macmillan, pp. 321-332.

Keynes, John Maynard (1936), The General Theory of Employment, Interest and Money, London: Macmillan.

Keynes, John Maynard (1981), The Collected Writings of John Maynard Keynes, Volume 20: Activities 1929-31: Rethinking Employment and Unemployment Policies, Donald Moggridge (ed.), Cambridge, UK: Cambridge University Press.

Krishnamurthy, Arvind and Annette Vissing-Jorgensen (2011), 'The effects of quantitative easing on interest rates: channels and implications for policy,' Brookings Papers on Economic Activity, Fall, 215-265.

Laubach, Thomas and John Williams (2003), 'Measuring the natural rate of interest,' Review of Economics and Statistics, 85, 1063-1070.

Mehra, Rajnish and Edward Prescott (1985), 'The equity premium: a puzzle,' Journal of Monetary Economics, 15, 145-161.

Mitchell, William, Randall Wray, and Martin Watts (2019), Macroeconomics, New York: Red Globe Press.

Nakamur, Emi and Jon Steinsson (2014), 'Fiscal stimulus in a monetary union: evidence from the U.S. regions,' American Economic Review, 104(3), 753-792.

Nucera, Federico, Andre Lucas, Julia Shaumburg, and Bernd Schwaab (2017), 'Do negative interest rates make banks less safe?' ECB Working Paper No 2098, September, Frankfurt: European Central Bank.

Phelps, Edmund (1961), 'The Golden Rule and accumulation: a fable for growthmen,' American Economic Review, 51, 638-643.

Piketty, Thomas (2014), Capital in the 21st Century, Cambridge, MA: Belknap Press. 
Rachel, Lukasz and Lawrence Summers (2019), 'On falling neutral real rates, fiscal policy, and the risk of secular stagnation,' Unpublished Manuscript, London School of Economics, Bank of England and Harvard University, March.

Radcliffe Committee (1959), Report of the Committee on the Working of the Monetary System, Cmd. 827, London: HMSO.

Romer, Christina and David Romer (2002), 'A rehabilitation of monetary policy in the 1950s,' American Economic Association Papers and Proceedings, 92, 121-127.

Schmelzing, Paul (2019), 'Eight centuries of global real rates, $R-G$, and the "suprasecular" decline, 1311-2018,' Unpublished Manuscript, Harvard University.

Summers, Lawrence (2014), 'U.S. economic prospects: secular stagnation, hysteresis and the zero lower bound,' Business Economics, 49, 65-73.

Tobin, James (1969), 'A general equilibrium approach to monetary theory,' Journal of Money, Credit and Banking, 1, 15-29. 